\title{
SURVIVAL AND CAUSE-SPECIFIC MORTALITY OF MERRIAM’S WILD TURKEYS IN THE JEMEZ MOUNTAINS, NEW MEXICO
}

\author{
Mark A. Peyton ${ }^{1,3}$, Sarah R. Kindschuh ${ }^{1}$, Lance J. Bernal ${ }^{2}$, Robert R. Parmenter ${ }^{1}$, and Philip S. Gipson ${ }^{2}$
}

AвstRaCt.-Merriam's Wild Turkeys (Meleagris gallopavo merriami) is a species of interest for managers and is considered economically valuable through wildlife viewing and hunting. We captured, radio-marked, and monitored 49 turkeys (27 males, 22 females) over a 3-year period (2008-2011) in the Valles Caldera National Preserve, Jemez Mountains, New Mexico. Annual Kaplan-Meier survival estimates varied among years (range 0.33-0.80). Lowest seasonal survival of 0.42 (SE 0.14) occurred during winter 2010 (1 Dec 2009-31 Mar 2010). We observed 20 fatalities of the 49 monitored turkeys. Predation by bobcats (Lynx rufus) and pumas (Puma concolor) accounted for 60\% ( $n=12$ ) of losses. Hunter harvest (20\%), vehicle collision (5\%), disease (5\%), and unknown causes (10\%) accounted for the remaining losses.

Resumen.-Los pavos de la especie Meleagris gallopavo merriami son una especie de interés para los gestores y se consideran valiosos económicamente tanto para su observación en vida libre como para la caza. Capturamos, marcamos con radios y monitoreamos 49 pavos (27 machos, 22 hembras) durante un período de tres años (2008-2011) en la Reserva Nacional Valles Caldera, en las Montañas Jemez, Nuevo México. La estimación anual de supervivencia de Kaplan-Meier varió según el año (rango 0.33 a 0.88). El valor más bajo de supervivencia de 0.42 (SE 0.14) ocurrió durante el invierno del 2010 (1 de diciembre del 2009-31 de marzo del 2010). Observamos 20 ausencias de los 49 pavos. La depredación de los linces (Lynx rufus) y los pumas (Puma concolor) explicaba el $60 \%(n=12)$ de las pérdidas. La temporada de caza (20\%), colisiones con vehículos (5\%), enfermedades (5\%), y dos causas desconocidas de muerte (10\%) justificaban las pérdidas restantes.

Merriam’s Wild Turkey (Meleagris gallopavo merriami) is native to the forested mountains of the Southwest and has been utilized by humans for at least 2000 years (Kennamer et al. 1992, Speller et al. 2010). Hunted nearly to extinction by the early 20 th century, Wild Turkey populations have experienced extensive recovery thanks to successful initiatives of wildlife managers (Kennamer et al. 1992). Ongoing management efforts focus on population reintroductions into formerly occupied mountain ranges, habitat enhancement, and hunting regulations.

Mammalian predation is the leading cause of fatality for Wild Turkeys (Rumble et al. 2003, Hughes et al. 2005, Lehman et al. 2005), although other animals (e.g., Great Horned Owl [Bubo virginianus], Golden Eagle [Aquila chrysaetos], American Crow [Corvus brachyrhynchos], and reptiles) are responsible for nest failure and predation (Ligon 1946, Miller and Leopold 1992, Hughes et al. 2005, Lehman et al. 2005). Adverse weather and food availability during winter, as well as hunting, influence survival of adult Wild Turkeys (Ligon 1946,
Oberlag et al. 1990, Wakeling 1991, Wakeling and Goodwin 1999, Lehman et al. 2005), with lowest survival recorded during winter and spring (Healy 1992, Vangilder 1992, Lehman et al. 2005).

Currently, the Valles Caldera National Preserve (VCNP) in the Jemez Mountains of northern New Mexico supports an estimated population of 300-500 Merriam's Wild Turkeys (L. Kamees, New Mexico Department of Game and Fish, personal communication). The Merriam's Wild Turkey is considered a species of interest for managers of the VCNP, and the VCNP population is economically valuable for wildlife viewing and hunting; however, little specific information on this population is available. The federal government purchased the VCNP from private ownership in 2000, and at that time predator control methods ceased. In 2004, the VCNP initiated limited spring maleonly turkey hunting. Therefore, beginning in 2008, we documented movement, habitat use, survival, and roost site characteristics of Merriam's turkeys in order to plan for preserve-wide watershed habitat restoration (using forest

\footnotetext{
${ }^{1}$ Valles Caldera National Preserve, Box 359, Jemez Springs, NM 87025.

${ }^{2}$ Department of Natural Resources Management, Texas Tech University, Box 42125, Lubbock, TX 79409.

${ }^{3}$ E-mail: mpeyton@vallescaldera.gov
} 
thinning and prescribed fire), sustainable-yield hunting programs, and public recreation activities. Herein, we report on the survival and cause-specific mortality of the study individuals.

The VCNP (35,560 ha) is located in Sandoval and Rio Arriba counties in northern New Mexico (North American Datum 27, Zone 13N, $363669 \mathrm{E}, 3976347 \mathrm{~N})$. Elevations range from $2439 \mathrm{~m}$ to $3431 \mathrm{~m}$. The vegetation is diverse, ranging from high-elevation spruce (Picea) forests down through mixed conifer and ponderosa pine stands, to the upper reaches of piñon-juniper (Pinus edulis-Juniperus spp.) woodlands; extensive montane meadows and grasslands are interspersed among the forested peaks (Anschuetz and Merlan 2007).

We captured turkeys from November through April in each year from 2008 to 2011 by using walk-in traps (Davis 1994), a drop net (Glazner et al. 1964), and a modified .308 caliber net rifle (Wildlife Capture, Flagstaff, AZ) at sites baited with cracked corn. We selected trap locations based on planned restoration activities. We affixed to each captured turkey a backpack-style radio-transmitter that weighed $\leq 120$ g (Lotek Wireless Fish and Wildlife Monitoring, Newmarket, $\mathrm{ON}$ ) and 2 uniquely colored butt-end aluminum leg bands (National Band and Tag Company, Newport, KY). Transmitters emitted a fatality pulse rate after 4 hours of inactivity and sustained a 3-year battery life. We located all individuals weekly using an omnidirectional (SRX 400) receiver and antenna tuned to each specific frequency (Lotek Wireless Fish and Wildlife Monitoring, Newmarket, ON). Once we received a signal, we used a handheld 3-element Yagi directional antenna to achieve locations without disturbing the birds. If we received a fatality signal, we located the carcass and determined the cause of death. We differentiated predation from other causes of death, such as disease or automobile collision, based on hemorrhaging and puncture wounds on the carcass. We identified mammalian predators by wounds on the carcass, as well as tracks, scat, and dorsal guard hairs at the kill or cache site. Sharp punctures accompanied by removal of the head or neck region indicated avian predation (Lehman et al. 2005). If cause of death was in question, we collected the carcass and performed a full necropsy at the VCNP laboratory.

We used the Kaplan-Meier statistic $(\hat{S})$ modified for staggered entry (Pollock et al. 1989) and also combined sex and age classes of turkeys for our annual and seasonal survival analysis. We identified seasons based on a combina-tion of study area climate (VCNP Valle Grande meteorological station, 2003-2011) and turkey behaviors, including winter flock formation and movements, breeding, nesting, laying, and brood-rearing (Ligon 1946, Spicer 1959, Shaw and Mollohan 1992, Hoffman et al. 1993). We classified 3 seasonal periods: 1 December31 March (winter), 1 April-31 July (spring), 1 August-31 November (fall). We assigned vegetation types using an existing ESRI ArcGIS VCNP vegetation layer (Muldavin et al. 2006). We also visually identified the dominant overstory species at turkey locations by using the same vegetation classifications.

We captured 49 turkeys consisting of 27 males (11 juveniles, 16 adults) and 22 females (6 juveniles, 16 adults). During our study, we observed 20 fatalities of the 49 monitored turkeys (Table 1). Predators accounted for $60 \%$ of recorded losses $(n=12)$, followed by legal harvest by hunters $(20 \%, n=4)$. Felines (Lynx rufus and Puma concolor) were the primary predators, with all felid predation occurring on male turkeys. Canids (Urocyon cinereoargenteus, Canis latrans, and Canis lupus familiaris) and birds were responsible for the remaining predation. Nonpredation fatalities included disease and highway vehicle collision (roadkill). We observed 2 deaths of unknown cause, but carcass remains were insufficient to identify diagnostic injuries, and we observed no identifiable tracks or hairs/feathers from predators to assign probable causes of mortality. Predation occurred in a variety of vegetation types (Table 1), with feline predation occurring primarily in riparian vegetation but also in ponderosa pine, piñon pine, and mixed conifer. Canid predation occurred in Gambel oak (Quercus gambelii) vegetation and at a private residence, and avian predation occurred in ponderosa pine/meadow edge and mixed conifer vegetation. All hunter harvest occurred off VCNP property on adjacent National Forest lands during male-only spring turkey hunts. Two turkeys died of nonpredationrelated causes: one vehicle collision (roadkill) occurred in winter along a state highway, and one female died showing clinical signs of histomoniasis (blackhead disease) in spring/early summer in mixed conifer vegetation.

Annual survival estimates for all turkeys ranged from 0.80 (SE 0.18) in 2008 to 0.33 
TABle 1. Cause-specific mortalities of Merriam's Wild Turkeys by sex, age (juvenile vs. adult), season (W = Winter, 1 Dec-31 Mar; S = Spring, 1 Apr-31 Jul; F = Fall, 1 Aug-31 Nov), and habitat type during 2008-2011 in the Jemez Mountains, New Mexico.

\begin{tabular}{|c|c|c|c|c|}
\hline Cause of mortality & Sex & Age & Season & Location/vegetation types \\
\hline \multirow{7}{*}{$\begin{array}{l}\text { Feline predation } \\
\quad(n=7)\end{array}$} & Male & Juvenile & $\mathrm{W}$ & Riparian \\
\hline & Male & Juvenile & $\mathrm{F}$ & Riparian \\
\hline & Male & Adult & W & Ponderosa pine \\
\hline & Male & Adult & W & Riparian \\
\hline & Male & Adult & W & Piñon-juniper \\
\hline & Male & Adult & $\mathrm{S}$ & Mixed conifer \\
\hline & Male & Adult & $\mathrm{S}$ & Riparian \\
\hline \multirow{4}{*}{$\begin{array}{l}\text { Hunter harvest } \\
\quad(n=4)\end{array}$} & Male & Adult & $\mathrm{S}$ & Santa Fe National Forest \\
\hline & Male & Adult & $\mathrm{S}$ & Santa Fe National Forest \\
\hline & Male & Adult & $\mathrm{S}$ & Santa Fe National Forest \\
\hline & Male & Adult & $\mathrm{S}$ & Santa Fe National Forest \\
\hline \multirow{3}{*}{$\begin{array}{l}\text { Canid predation } \\
\quad(n=3)\end{array}$} & Female & Juvenile & W & Gambel oak \\
\hline & Female & Adult & W & Gambel oak \\
\hline & Male & Juvenile & W & Residential \\
\hline \multirow{2}{*}{$\begin{array}{l}\text { Avian predation } \\
\quad(n=2)\end{array}$} & Female & Juvenile & $\mathrm{F}$ & Meadow edge \\
\hline & Female & Adult & $\mathrm{F}$ & Mixed conifer \\
\hline $\begin{array}{l}\text { Vehicle collision } \\
\quad(n=1)\end{array}$ & Male & Adult & W & Highway \\
\hline $\begin{array}{l}\text { Disease } \\
\qquad(n=1)\end{array}$ & Female & Adult & $\mathrm{S}$ & Mixed conifer \\
\hline \multirow{2}{*}{$\begin{array}{c}\text { Unknown } \\
(n=2)\end{array}$} & Female & Adult & W & Ponderosa pine \\
\hline & Male & Adult & $\mathrm{F}$ & Mixed conifer \\
\hline
\end{tabular}

(SE 0.06) in 2010 (Fig. 1A). The Las Conchas wildfire, which began on 26 June 2011 and burned a total of $630 \mathrm{~km}^{2}$, including over $30 \%$ of the VCNP, disrupted the field monitoring schedule, so we did not calculate annual survival estimates for 2011. Our observed range of annual survival rates $(0.33-0.88)$ was comparable to ranges reported in other studies on Merriam's turkey, with winter conditions heavily influencing temporal fluctuations in survival (Vangilder 1992, Rumble et al. 2003, Hughes et al. 2005). These other studies found that mammalian predation accounted for the majority of mortality: coyotes were the primary predator of females in Arizona and South Dakota (Rumble et al. 2003, Lehman et al. 2005). Hughes et al. (2005) states that bobcats are the most commonly reported predator of both turkey hens and gobblers. Ligon (1946) and Spicer (1959) identified bobcats as the primary predator in New Mexico.

Winter 2010 showed the lowest seasonal survival estimate of 0.42 (SE 0.14 ). All of the remaining seasons indicated $\geq 0.73$ survival (Fig. 1B); note that survival was constant from early spring through mid-autumn in $2008(n=$ 5 individuals) and 2009 ( $n=8$ individuals), with no observed fatalities after the winter season in those years (Fig. 1). We observed tagged turkeys moving to lower elevations during the winter season, with overwintering grounds on private property and the Santa Fe National Forest. These movements coincided with the arrival of deep snow combined with colder temperatures at higher elevations. We observed that winter movements introduced additional risks that were not present on the VCNP, including increased hunting pressure, highway traffic, and domestic dogs. Late winter precipitation in March 2010 (43 mm) led to an extended snowpack through April, several weeks longer than in 2008 and 2009 (March precipitation of 4 and $24 \mathrm{~mm}$, respectively). These conditions may have contributed to the low survival rates recorded during winter 2010 by increasing movement distances during seasonal shifts, concentrating flock activity, decreasing physiological condition of turkeys, and making the turkeys more susceptible to predation (Spicer 1959, Healy 1992, Rumble and Anderson 1996, Wakeling and Rogers 1996).

Our observations indicate that current hunting activities by humans caused $20 \%$ of total turkey mortality, affecting $8 \%$ of the population (15\% of adult males). Since 2008 , management of turkey hunts in the preserve and the Jemez Mountains appears to maintain sustainable populations, but continued monitoring will be required to ensure long-term population stability, particularly with respect to increased 


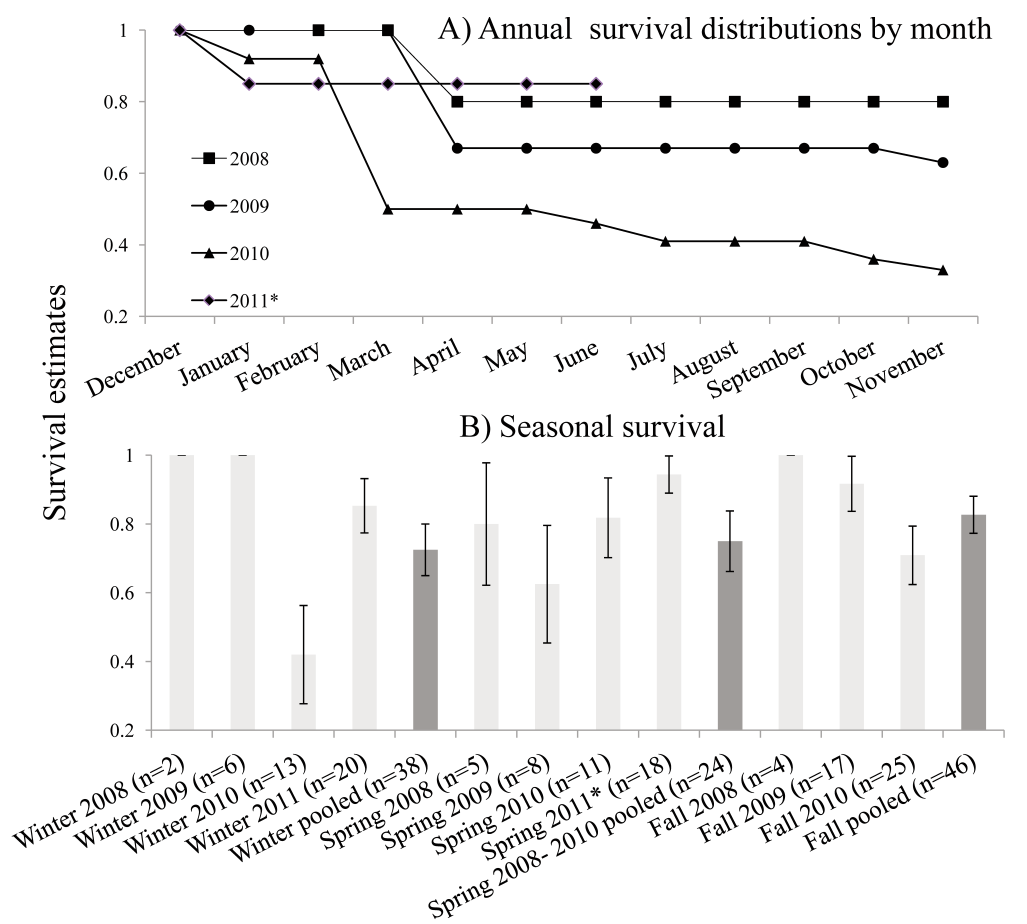

Fig. 1. Kaplan-Meier survival estimates for Merriam's Wild Turkeys in the Jemez Mountains, New Mexico, 20082011: A, annual survival distributions (1 Dec-30 Nov); B, seasonal (Winter, 1 Dec-31 Mar; Spring, 1 Apr-31 Jul; Fall, 1 Aug-31 Nov) survival estimates ( \pm SE). *The Las Conchas fire began on 26 June 2011 and prevented data collection before the spring season was complete.

human recreation, wildland fires, and forest restoration activities.

We thank Marc Chipault for his direction in project implementation; Niki VonHedemann and William Meyer for their dedicated fieldwork; and Michael Jasper, Scott Leirich, Larry Kamees, Deborah Finch, and Randy Isler for their advice and guidance. We thank Mark Wallace, Carol Chambers, and anonymous referees for reviewing previous versions of this manuscript. We thank and remember the late Warren Ballard for his advice during the early phases of the project. Funding and logistical support was provided by the VCNP, the USDA Forest Service Rocky Mountain Research Station, the National Wild Turkey Federation, and the New Mexico Department of Game and Fish.

\section{Literature Cited}

Anschuetz, K.F., and T. Merlan. 2007. More than a scenic mountain landscape: Valles Caldera National Preserve land use history. General Technical Report RMRS-GTR-196, U.S. Department of Agriculture,
Forest Service, Rocky Mountain Research Station, Fort Collins, CO. 277 pp.

DAvis, B.D. 1994. A funnel trap for Rio Grande turkey. Proceedings of the Annual Conference of the Southeastern Association of Fish and Wildlife Agencies 48:109-116.

Glazner, W.C., A.S. Jackson, and M.L. Cox. 1964. The Texas drop-net turkey trap. Journal of Wildlife Management 28:280-287.

Healy, W.M. 1992. Population influences: environment. Pages 129-143 in J.G. Dickson, editor, The Wild Turkey: biology and management. Stackpole Books, Harrisburg, PA.

Hoffman, R.W., H.G. Shaw, M.A. Rumble, B.F. WakelING, C.M. Mollohan, S.D. Schemnitz, R. EngelWilson, AND D.A. Hengel. 1993. Management guidelines for Merriam's Wild Turkey. Colorado Division of Wildlife, Division Report No. 18.

Hughes, T.W., J.T. Tapley, J.E. Kennamer, and C.P. LehMAN. 2005. The impacts of predation on Wild Turkey. Proceedings of the National Wild Turkey Symposium 9:117-126.

Kennamer, J.E., M. Kennamer, and R. Brenneman. 1992. History. Pages 6-17 in J.G. Dickson, editor, The Wild Turkey: biology and management. Stackpole Books, Harrisburg, PA.

Lehman, C.P., L.D. Flake, and M.A. Rumble. 2005. Survival and cause-specific mortality of Merriam's turkeys in the southern Black Hills. Proceedings of the National Wild Turkey Symposium 9:117-126. 
LigON, J.S. 1946. History and management of Merriam's Wild Turkey. University of New Mexico Publications in Biology 1.

Miller, J.E., AND B.D. Leopold. 1992. Population influences: predators. Pages 119-128 in J.G. Dickson, editor, The Wild Turkey: biology and management. Stackpole Books, Harrisburg, PA.

Muldavin, E., P. Tonne, C. Jackson, and T. Neville. 2006. A vegetation map of the Valles Caldera National Preserve, NM. Final Report for Cooperative Agreement No. 01CRAG0014, University of New Mexico, Natural Heritage Museum, Albuquerque, NM.

Oberlag, D.F., P.J. Pekins, and W.W. Mautz. 1990. Influence of seasonal temperatures on Wild Turkey metabolism. Journal of Wildlife Management 54: 663-667.

Pollock, K.H., S.R. Winterstein, C.M. Bunch, And P.D. CuRTIS. 1989. Survival analysis in telemetry studies: the staggered entry design. Journal of Wildlife Management 53:7-15.

Rumble, M.A., AND S.H. ANDERson. 1996. Feeding ecology of Merriam's turkeys (Meleagris gallopavo merriami) in the Black Hills, South Dakota. American Midland Naturalist 136:157-171.

Rumble, M.A., B.F. WaKeling, and L.D. FlaKe. 2003. Factors affecting survival and recruitment in female Merriam's turkeys. Intermountain Journal of Sciences 9:26-37.

Shaw, H.G., and C. Mollohan. 1992. Merriam's turkey. Pages 331-349 in J.G. Dickson, editor, The Wild Turkey: biology and management. Stackpole Books, Harrisburg, PA.
Speller, C.F., B.M. Kemp, S.D. Wyatt, C. Monroe, W.D. Lipe, U.M. ARNDT, AND D.Y. YANG. 2010. Ancient mitochondrial DNA analysis reveals complexity of indigenous North American turkey domestication. Proceedings of the National Academy of Sciences of the United States of America, www.pnas.org/cgi/doi/ 10.1073/pnas.0909724107

SPICER, R.L. 1959. Wild Turkey in New Mexico: an evaluation of habitat development. New Mexico Department of Game and Fish Bulletin 10.

VAngiLDer, L.D. 1992. Population dynamics. Pages 144-164 in J.G. Dickson, editor, The Wild Turkey: biology and management. Stackpole Books, Harrisburg, PA.

Wakeling, B.F. 1991. Population and nesting characteristics of Merriam's turkey along the Mogollon Rim, Arizona. Arizona Game and Fish Department Research Branch Technical Report 7.

WaKeling, B.F., and J.G. GoOdWIn JR. 1999. Merriam's turkey winter survival on the North Kaibab Ranger District following the Bridger Knoll complex fires. Proceedings of the Biennial Conference of Research on the Colorado Plateau 4:123-132.

Wakeling, B.F., AND T.D. Rogers. 1996. Characteristics of pinon-juniper habitats selected for feeding by wintering Merriam's turkey. Pages 74-79 in D.W. Shaw, E.F. Aldon, and C. LoSapio, technical coordinators, Desired future conditions for pinon-juniper ecosystems. General Technical Report RM-258, USDA Forest Service.

Received 20 May 2013 Accepted 9 May 2014 